Vol. 6(1997): 337-339.

\title{
First report of Diuraphis (Holcaphis) frequens as a pest of wheat in Finland
}

Jonathan Robinson

Agricultural Research Centre of Finland, Institute of Crop and Soil Science, Plant Breeding Section, FIN-31600 Jokioinen, Finland, e-mail: jonathan.robinson@mtt.fi

\begin{abstract}
Colonies of Diuraphis (Holcaphis) frequens (Walker) were found on wheat, Triticum aestivum L. in the vicinity of Jokioinen in south-west Finland in summer 1997. The aphid was present in all wheat fields inspected, and was particularly abundant on spring wheat plants of field and plot margins. The aphid was also common on its recognised, host Elymus repens (L.) Gould (couch grass). Damage symptoms, longitudinal chlorotic streaking of tightly rolled leaves, resembled those caused by Diuraphis noxia (Mordvilko), the Russian wheat aphid. Diuraphis frequens appears unlikely to become a serious pest of wheat, and its relative abundance during 1997 may have resulted from particularly hot, dry weather.
\end{abstract}

Key words: aphid, Aphididae, Elymus repens, Homoptera, Insecta, pest, Triticum aestivum

\section{Introduction}

Diuraphis (Holcaphis) frequens (Walker) is widespread in the Nordic countries, Europe and Asia where its host plant is couch grass, Elymus repens (L.) Gould (Heie 1992), a common weed of agricultural land. It was recorded on wheat, Triticum aestivum L. from Idaho (Halbert et al. 1992) and Colorado (Anderson et al. 1995) in the United States, although it was not recorded as a serious pest, nor was it anticipated to become one. To date this aphid has not been estimated to be a pest of wheat in Finland, although it was observed on wheat in Finland in 1994 (Hannu Ahokas pers. comm.).

\section{Material and methods}

Observations were made on spring wheat plants, and plants of E. repens, in and around the Jokioinen area in south-west Finland $\left(60^{\circ}\right.$ $\left.49^{\prime} \mathrm{N}, 23^{\circ} 30^{\prime} \mathrm{E}\right)$ during July and August 1997. Leaves with symptoms of $D$. frequens infestation were removed to the laboratory where they 
Robinson, J. Diuraphis frequens on wheat

were unrolled and aphids, including viviparous apterates and alates, and nymphs, were observed and photographed under a binocular microscope.

\section{Results and discussion}

Diuraphis frequens is widespread in Finland (Heie 1992), but has not previously been recognised as a pest of wheat. The aphid was found on spring wheat plants from all wheat plots sampled in the vicinity of Jokioinen, during July and August 1997. It was also noted in other wheat fields of south-west Finland (Marja Jalli pers. comm.) and can be presumed to have been more widely distributed than was immediately apparent. It was found on all leaves, up to the flag leaf. It was particularly abundant on wheat plants around field and plot margins. It was also found in abundance on couch grass, its preferred host. Plants of barley, Hordeum vulgare L., oats, Ave na sativa $\mathrm{L}$. and rye, Secale cereale $\mathrm{L}$. were observed but the aphid was not recorded on hosts other than wheat and couch grass.

The apterous viviparous female aphid is light green and wax-powdered, with black antennae, cauda and legs. The apterate is up to $2.5 \mathrm{~mm}$ long. The alate viviparous female has a light green abdomen and a dark head and thorax. Diuraphis frequens is described in detail by Heie (1992).

Damage symptoms on wheat and E. repens resembled those caused by D. noxia (Robinson 1994). The aphid formed colonies on new leaves, which remained tightly rolled, effectively concealing the aphid (Figure 1). Longitudinal chlorotic streaks were evident in infected leaves indicating that the aphid injects a toxin into the plant while feeding similarly to $D$. noxia. While chlorotic streaking was evident on leaves of couch grass, it was more evident on wheat leaves. Diuraphis frequens was frequently found in association with the bird-cherry oat aphid, Rhopalosiphum padi (L.). There is no evidence that $D$. frequens transmits virus, but interestingly Bremer (1964) failed to transmit Agropyron mo-

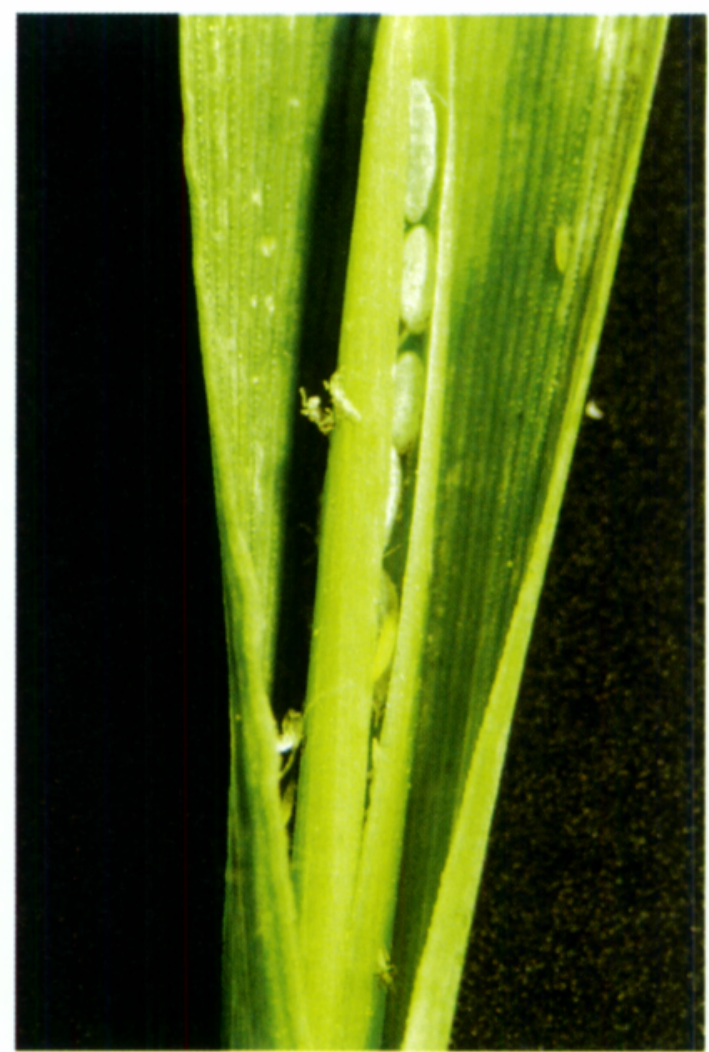

Fig. 1. Colony of Diuraphis (Holcaphis) frequens feeding within a tightly rolled wheat leaf. (Photo: Jonathan Robinson).

saic with several common cereal aphids, but did not test the ability of $D$. frequens to transmit it.

Diuraphis frequens was adversely affected on wheat by heavy rain during late July/early August, but appeared less affected on couch grass. Following heavy rain, colonies became infected by several species of entomopathogenic fungi. Syrphid larvae appeared to be the principal predators of the aphid.

Diuraphis frequens was thought unlikely to reach serious pest status on wheat in Idaho (Halbert et al. 1992) and has not been recorded as causing economic loss on wheat in Colorado (Anderson et al. 1995). It appears that it is unlikely to reach serious pest status in Finland. Due to its cryptic feeding habits, and association with $R$. padi, it may have been present on wheat for 
Vol. 6 (1997): 337-339.

some time in Finland but has gone unnoticed, or unrecorded. Attempts to maintain the aphid in the greenhouse on wheat enclosed in transparent plastic tubes was unsuccessful, probably due to its inability to tolerate high humidity. The particularly hot and dry summer of 1997 may have been conducive to its seemingly uncharacteristic prominence.

\title{
References
}

Anderson, A.E., Holtzer, T.O. \& Michels, G.J. 1995. Comparative growth rates of the Russian wheat aphid, Diuraphis noxia (Homoptera, Aphididae), and other Diuraphis species in Colorado. Bulletin of the Ecological Society of America 76: 4-5.

Bremer, K. 1964. Agropyron mosaic virus in Finland. Annales Agriculturae Fenniae 3: 324-333.

Halbert, S.E., Connely, B.J. \& Feng, M.-G. 1992. Occurrence of Diuraphis (Holcaphis) frequens (Walker) (Homoptera: Aphididae) on wheat, new to Idaho, and a key to North American Diuraphis. Pan-Pacific En- tomologist 68: 52-61.

Heie, O.E. 1992. The Aphidoidea (Hemiptera) of Fennoscandia and Denmark. IV. Fauna Entomologica Scandinavica 25. E. J. Brill, Leiden, The Netherlands p. 98-105.

Robinson, J. 1994. Identification and characterization of resistance to Russian wheat aphid in small-grain cereals: investigations at CIMMYT, 1990-1992. CIMMYT Research Report No. 3 Mexico, D.F.: CIMMYT. $44 \mathrm{p}$.

\section{SELOSTUS}

\section{Diuraphis frequens -kirva vehnässä}

\author{
Jonathan Robinson \\ Maatalouden tutkimuskeskus
}

Diuraphis (Holcaphis) frequens (Walker) yhdyskuntia löytyi vehnästä, Triticum aestivum L., LounaisSuomesta Jokioisten lähiympäristöstä kesällä 1997. Kirvoja esiintyi kaikissa tutkituissa vehnäpelloissa, erityisesti kevätvehnäpeltojen ja -ruutujen reunaalueilla. Kirvoja oli runsaasti myös sen varsinaisella isäntäkasvilla juolavehnällä, Elymus repens (L.) Gould. Vioitusoireet, pitkittäiset kloroottiset juovat vahvasti kiertyneissä lehdissä, muistuttavat toisen vehnää vioittavan kirvan, Diuraphis noxia (Mordvilko), 'Russian wheat aphid', aiheuttamia oireita. Diuraphis frequens -kirvasta ei todennäköisesti tule vakavaa vehnän tuholaista, sillä erityisen lämmin ja kuiva sää kesällä 1997 mahdollisti kirvan runsaan esiintymisen. 